\title{
Anatolian Cultural Heritage: Ancient Stadiums Related to Sport or Physical Culture?
}

\author{
Aylin Zekioglu*, Naci Kalkan \\ Faculty of Sports Science, Manisa Celal Bayar University, Turkey
}

Copyright $\mathrm{C} 2019$ by authors, all rights reserved. Authors agree that this article remains permanently open access under the terms of the Creative Commons Attribution License 4.0 International License

\begin{abstract}
Anatolia has hosted many civilizations and has made great contributions to the history of humanity in scientific, social and cultural terms. Two of the most important cultures that make up this cultural heritage in Anatolia are Hellenic and Roman culture. The material and intangible cultural heritage of this turnover is still alive in Anatolia, which is home to the Hellenistic and Roman cultures. In our work, we have studied material cultural heritage, stadiums of Hellenistic and Roman culture. The aim of these stadiums is to assess the architecture, culture, lifestyles, social rules of different periods on a case appealing to large communities such as sports. This study, which deals with the effects of the legacies left by the civilizations that lived in the Anatolian geography in the historical perspective of the sport, also aims at shedding light on the sportive activities made at that time at the same time. The stadiums studied in the study include Didyma, Ephesos, Magnesia, Miletus, Priene, Smyrna, Aphrodisias, Labranda, Blaundos, Nysa, Sardeis, Arykanda, Kadyanda, Letoon, Pergamon, Aspendos, Sillyon, Perge, Aizanoi, Laodikeia, Selge are stadiums located in the ancient cities.
\end{abstract}

Keywords Anatolia, Ancient, Stadiums, Cultural, Sport

\section{Introduction}

Society refers to an entity that consists of individuals and groups, exceeding their sum [1]. Culture implies and represents all the products of all the structures that make up society [2]. In other words, culture, people and society together express production. This relationship; we can express it as the cultural heritage of all the material and intangible accumulation of the material that was transferred from the past. Examples of material cultural heritage are worship places, monuments, historical artifacts, stadiums, etc. It covers everything that man has left behind, which is left for future generations. In addition to the material cultural heritage, the intangible cultural heritage is also important in shaping the cultivated culture, making the humanities, customs, traditions, customs and beliefs permanent. These tangible and intangible cultural elements can be observed directly, with 118 currently being preserved ancient city in Turkey and the Anatolian geography of our world is of great importance.

Stadium means a sports facility that is designed specifically for sports competitions [3]. It is a structure that consists of an area for organizing a sportive event and an area allocated for audience to watch this event. Although the underlying logic is the same, it is known that many stadium designs were made and built in various shapes and quality in many geographical regions of the world throughout the history [4]. In the Ancient Greek Civilization, physical education activities and athletic games were in agoras in early periods, and then in stadiums, gymnasiums and hippodromes; and in this context, the palestras, eliothesiums (oiling rooms), baths constituted indispensable parts of gymnasiums. In ancient times, physical education and sports activities were considered important, and agoras in cities were used for these purposes and to raise young people in early periods [5]. In agoras, where games and sports activities were organized, it was observed that ceremonial running competitions were organized; however, agoras were not adequate to cover these needs and it was difficult to control the audience in such areas in the competitions organized in these areas [6].

Young people who were educated in gymnasiums where there were different activity areas according to age groups had the rest of soul in small sanctuaries in these areas before they started sportive activities [7]. There were running tracks, and disk and javelin throw areas in gymnasiums [8]. In following periods, changing rooms, baths, classrooms and conversation rooms were added [9]. Palestras, where fight sports and jumping competitions were organized, had a rectangular shape, and were covered at the top surrounded with columns. One of their main functions was to provide athletes with an indoor area to workout in bad weather conditions. There were at least one Palestra, which belonged to private entities, in each city until the end of the Roman Empire in the 6th Century B. C., 
and mostly only members could use them. In some Palestras, there was skamma, which was filled with sand for wrestling, and keroma, which was watered and filled with mud for ground wrestling and wrestling in pancration, just like in the Olympia [8].

Before the physical education and sports activities that were performed in gymnasiums in antiquity, young people and the athletes who would compete in games oiled each other with olive oil in rooms that were called eliothesium, and those who would wrestle would cover their bodies with sand in konisterum, which constitute important parts of gymnasium and palestras. There were also bathrooms and washing rooms called loutron, built or added as a part of gymnasium and palestras [5].

Stadiums have an important place in ancient Greek culture. Stadium was first brought into the agenda as an idea and application during the ancient Greek civilization. This idea was developed and changed throughout history in terms of idea, design and meaning according to the social change process. Although the understanding and structure of stadiums of each period were similar to previous and following ones in terms of the underlying logic, they differ from each other in details [4].

Stadiums were built in different architectural designs in Greek, Hellenic and Roman periods in city states of Anatolia. Due to the requirement of bigger areas in the building of stadiums, they were built outside city walls, which is also the case in Perge, and sometimes were built in suburban areas within the city by considering the natural status and ground formations of the area [6,9].

The aim of this study is to present the cultural heritage and the ancient stadiums of Anatolia and to shed light on the sportive activities made at that time.

\section{Materials and Methods}

To collect data in this study; books, articles, dissertations, papers were investigated. At the same time, the ancient cities were examined on site and various observations were made.

\section{Results}

The data on ancient stadiums in Aegean and Mediterranean regions were collected. Some of them like Aphrodisias, Perge, Saittai are well-preserved. Some of them like Tralleis and Smyrna were destroyed in history. The existence of some of them like Myndos are known with the help of the travel notes of travelers in these areas or with the help of inscriptions. Some of them are controversial in that whether they are stadiums or not like Pitane and Rhodiapolis, which are only guessed to be stadiums.

Didyma: It is a center located in $16 \mathrm{~km}$ south of ancient Miletos and is famous for its Apollon Temple and sacred area. The stadium is located in the southern part of the temple. It is understood that this temple was used under sacred conditions about the religious ceremonies in the ancient Didyma. About 250 names that belonged to audience carved on the steps of the temple show that these steps were also the place to watch the start and finish of competitions $[6,10]$.

Ephesos: The stadium is located in the eastern part of the Acropolis in ancient Ephesos north to the grand theatre on the skirts of the Panayir mountain. The stadium was built during the Hellenistic period and was restored and expanded during the period of Neron. The stadium is in ruins today. Because of the reinforcement area built on the top of the hill located in Selcuk, the stones were pillaged. The rows in the stadium showing good workmanship in terms of the inscriptions on them were used during the restoration and building in $4^{\text {th }}$ and $6^{\text {th }}$ Centuries in Ephesus. The stadium is $230 \mathrm{~m}$ long and $40 \mathrm{~m}$ wide. No start line can be observed in this stadium. The slopes of the mountain were made use of for the place of audience and the sitting steps were placed on the slope without having to use larger infrastructure on the long edge at the southern part of the stadium. There are marble plates revealed today on the western side. These plates were brought from other areas and were used here. These plates, which have figures of date branches, vase, and rabbits on them, depicting the rewards given in some sports competitions. A gaming area was allocated on the eastern edge of the stadium which has the shape of semi-circle and was used for the fights of the gladiators and wild animals. This area is specific to the Roman culture, because there were no other places to be used as an arena. During these shows, Christians were slain. For this reason, after Christianity was accepted as the formal religion, the Ephesus stadium was destroyed by religious people $[11,6,10]$.

Magnesia: The structures seen today in Magnesia belong to the Roman Empire Period and to later times. Gymnasium was a sports-based training center and was a smaller copy of the Faustina Bath in Milet. There is also Odeion, which is a stadium located between the theatre and Artemision that could host 25.000 people. The stadium was located on a slope of a mountain, which stretched from the north to the south. This stadium has the U-plan and double-sided sitting places and is located on the south of the Gymnasium. The entrance of the running track was determined with a front gate. The length of this road was $185,90 \mathrm{~m}$ until the starting point of the semi-curve. A partial protection structure attracts attention in this stadium $[12,6]$.

Miletus: The eldest hellenistic stadium of Anatolia is at Miletus. Ancient Miletus lived the most prosperous period in the $6^{\text {th }}$ and $7^{\text {th }}$ centuries A. D. The stadium is located on the theater in the general plan and is in the southern part of the theatre bay. The plan of it is in a rectangular fashion and has cornered edges. The sitting places stretch along the long sides. There are twenty sitting rows on each side. It is 
estimated that there were places for 14 thousand people in the stadium. The length of the running track is $191,39 \mathrm{~m}$., and the width is $29,56 \mathrm{~m}$. This stadium was built in the middle $2^{\text {nd }}$ Century A. D. (150 A.D.) in the Hellenistic Period in line with the city plan in itself. It was restored in the late Roman Period [11,6,13].

Priene: It is located near the southern wall in the lowest part of the city. It is adjacent to the Gymnasium in its north-western part. Its plan is in a rectangular shape and has edges. The 1-m thick terrace walls of the stadium which were reinforced with supports on sides may be still seen today. Due to the structure of the field in the area, there was only a place for the audience on the northern side of it. One third of the middle part of the stadium and the running track has been excavated today. The length of the running track is approximately 191 meters long, and the width is $20 \mathrm{~m}$. It is seen that the lower gymnasium and the stadium are not in line with the principles in the city plan and are separated from the other structures in the city $[10,11]$.

Smyrna: The stadium is disrupted very much. The sitting places on the southern and eastern part of the stadium were built by preserving the slope of the hill. The sea was visible from the honor place in the eastern edge. During the reign of L. Statius Quadratus (A.D. 154-155) St. Polikarp was martyred in this stadium $[14,15]$.

Aphrodisias: The stadium stretches along the eastern and western side of the city. It is one of the best-preserved stadiums in Anatolia. It is said to have a capacity of approximately 30 thousand audience. Each sides of the stadium are in the shape of semi-circle and there are tunnel entrances in each edges. The running track is in the size of $262 \times 59 \mathrm{~m}$. Various competitions and athletic games were always organized in the stadium during the festivals in the city. However, as a result of the earthquakes that took place in the $7^{\text {th }}$ Century, there were damages in the city theater and the eastern side of the stadium was converted into an area for arena games. Athletes always had a special position $[6,16]$.

Labranda: Nothing has been left of this stadium in our present day. Since the middle part of the stadium was converted into a cemetery, it is not possible to see the running track. According to the ruins, there were places where runners would rest their left feet before starting running. Although it is not clearly known for certain when the stadium was built, it is possible that it was built later mid- $4^{\text {th }}$ Century A. C. $[6,16]$.

Blaundos: The remains of the stadium are seen in the northern side behind the grand gate that was the only entry of the walls in the city. There are places for audience only in one side in this stadium, which is the case in ancient Priene [6].

Nysa: Just like it was the case in Roman cities, one of the most important structures of the ancient Nysa was the Gymnasium. Mental and bodily education and training were provided for young people in this school. The stadium of the city, i.e. the amphitheater, was approximately 192 meters long and 44 meters wide and had the capacity of hosting approximately 30.000 people. It was determined that there were 30 sitting places [6].

Sardis: The vaulted structure in the form of a long line just below the Acropolis represent the northern side of the stadium. The southern side was built on a natural slope. The eastern side stretches towards the skirts of the former theater. The architecture of the stadium and the theater attract attention in the ancient Sardis [6].

Arykanda: The stadium is located on one of the top terraces of the ancient Arykanda. The niches have been revealed behind the sitting places of the stadium. The size of them are half the normal stadium size. The length of it is $80 \mathrm{~m}$, and the width is $16 \mathrm{~m}$ [6].

Kadyanda: The stadium stretches along the western-eastern line in the city center as a plain area with its more than $90 \mathrm{~m}$ length. Since the both ends of the stadium were destroyed, it is not possible to determine the first size. It is estimated to be 180 meters long. The inscriptions mention athletic ceremonies in the ancient Kadyanda. The inscriptions in the stadium, which belong to the same period, have been destroyed [6].

Letoon: According to the inscriptions, the existence of the stadium, whose place and shape have not been determined yet in ancient Letoon, is important because it proves that this place was not only a cultural center but was also a living city [6].

Pergamon: The stadium was located in the lower city. It was formed during Roman period. The slope of the hills in the area were benefited in building the southern part of the Gymnasium in the ancient Pergamon, and thus, the place which is now called as the Bodrum Stadium was formed $[17,6]$.

Aspendos: It is located in the northern part of the stadium and in the eastern side of the Acropolis. It has a U-shaped plan and was made of stone. The length of the running track was $215 \mathrm{~m}$, and the width was $30 \mathrm{~m}$. The starting line is not visible. The sitting places in the stadium were built on arches. The northern edge that is round is facing the east [4].

Sillyon: The stadium is located on the southeastern part of the city and was built in the U-shaped fashion. The sitting places were located only on the eastern part and 4 well-preserved rows may be seen today. No sitting places are visible on the western side. The Ancient Sillyon was built towards the mid- $2^{\text {nd }}$ Century A. D. [6].

Perge: The stadium is located completely outside the city walls facing the theater. This stadium is one of those which were preserved well and had a U-shaped structure. The length of the running track was $234 \mathrm{~m}$, and the width is $34 \mathrm{~m}$. The starting line has not been preserved. The sitting places of the stadium were built on arches. The number of the sitting steps is 12 and the capacity of the stadium is 12 thousand people. The southern side of the stadium is open. Remains of a half column, statues and column headings 
were found in this edge. It is understood that these remains belonged to a monumental door. The ancient Perge stadium was probably built in the $2^{\text {nd }}$ Century A. D. $[6,15]$.

Aizanoi: The process of building of the stadium is known to start in $160 \mathrm{~A}$. D. and continued until the mid- $3^{\text {rd }}$ Century A. D. with intervals. The inscriptions that were found during the restoration of the eastern part of the entry of the stadium, which were later placed to their original resting places again, show that M. Apuleius Eurykles, whom we know from the inscription of the main bridge, played a role in the building of this complex. Since the sitting rows of the stadium are slightly in the form of a polygon, the structure is expanded in the middle part. In the widest point, there is a gate opening to western side. The side of the theater facing the theater is limited with a wall [6].

Laodikeia: The stadium stretches along the south-west and east-west direction. The stadium was built to have an integrity with its additional structures and the Gymnasium. The length of the stadium which was built in $79 \mathrm{~A}$. D. is $350 \mathrm{~m}$., and the width is $60 \mathrm{~m}$. The structure which was built in the form of amphitheater had a sitting row with 24 steps. A great deal of it has been destroyed. The gymnasium was built by proconsul Gargilius Antiquus in the $2^{\text {nd }}$ Century A. D. An inscription was found saying that the building was devoted to the Emperor Hadrianus and his wife Sabina $[18,15]$.

Selge: The stadium is located on the southwestern part of the theater on a plain area that is parallel to the city. The length of the running track is $216 \mathrm{~m}$, and the width is $40 \mathrm{~m}$. The starting point was not preserved. The stadium was made of stone. The theater and the stadium show parallel architecture to each other in ancient Selge. The stadium is located on the southwestern part of the theater. Here, the structure is different from the theater-stadium connection which was found in ancient Aizanoi. The inscriptions mention the competitions organized in the stadium [15].

\section{Conclusions}

Stadiums have shown variations among cultures. For example, it is known that the Greek built larger stadiums and Romans preferred arenas. Similarly, although the Greek used the stadiums for competitions, Romans used them for wild animal fights and gladiator shows. The stadiums were accepted as the areas where especially athletics shows were organized widely in Roman states of Asia Minor in Roman period in 500s B.C. Still, the indispensable elements of games the athletic shows are among the main events in such buildings [19]. In this respect, one of the most important features of ancient stadiums that resemble and that separate them from the stadiums today is the purpose of use. Ancient period stadiums were different from the stadiums of our present day because they were generally used for athletics-based sports activities. However, they also resemble the stadiums of our present day because the activities that addressed wide audience like folkdances and competitions were held in these areas when necessary [4].

All that aside, parallel to the acquisition of their own cult identity by athletes and with the professional games as of 5th Century B. C., games were also abstracted from their religious identity and had the quality of being an entertainment-focused activity, which changed the structure and character of stadiums [20]. In this way, stadium lost its religious meaning and was excluded from being understood as a sacred area; and emerged a new as a concept specific to the history of sports. Today, in the world where we live and which we have to claim, we are facing a world that is polluted at a fast pace. About the good and beautiful one, it is difficult to reach the historical understanding that examines the approaches of the philosophers of those times that deal with the series of values and the importance given to physical culture of the Greek civilization. The three great philosophers, Socrates, Plato and Aristoteles, emphasized the connection between sports and music and mathematics in the maturity period of the Classical Greek Philosophy. They understood sports as an element of being ethical and as an element of living an honest and regular life [21]. According to Aristoteles, gymnastics is "the research method for searching which movement is useful for the body, and which of the movements are better and suitable for the qualities granted by the nature to the human body in a proportional manner" [22]. In this respect, Plato said "Each living entity wants to jump with their instincts. This has a rhythm that is specific to it. Dance and music emerged from this. Young creatures do not stay calm with their bodies and sounds, they jump in an irregular manner, and make noise. However, people have a harmony which is called rhythm and is the agreement of low and high pitches" [22]. According to Socrates, gymnastics is "A moral task that has to be fulfilled to give the body beauty and power. Questioning it is the biggest shame" [22]. Based on this, when we consider the sportive activities in ancient times, all of the ancient Olympic games were organized in stadiums.

The basic principle to be formed in today's sports activities is bringing new values to the stage by bringing together all national sportsmen, regardless of race, religion and language. The fact that the history of the sport also has important traces on the history of humanity makes it possible to make inferences about the Hellenistic and Roman cultures in Anatolia. Some of the stadiums we studied in the study were found to be in very good condition, some of them being destroyed, some of them being stadiums with inscriptions from traveler's notes.

Ancient stadiums were used for different purposes during the periods they were used. Most of the stadiums were destroyed due to natural disasters and wars. The protection of these structures is closely linked to the sphere 
of view of society and generally to values. Protecting the stadiums that have survived as well as the necessary restorations is the main task of all civilized societies. This study, which sought to revive Anatolia's rich sports culture and bring it to the agenda by exploring the richness of Anatolia in terms of antique stadiums, suggests that preserving cultural heritage is important for future generations.

\section{REFERENCES}

[1] Eliot Thomas Stearn; Kultur uzerine Dusunceler, cev. Sevim Kantarcioglu, Mas Matbaacilik, 1. Baski, Ankara, 1987

[2] Sahin M.;Spor Ahlaki ve Sorunlari, Evrensel Basim Yayim, Istanbul, 30-32, 1998

[3] Durgun, Dogan; “Turkiye'de Sporun Gelisimi ve Degisen Kullanıc1 Gereksinimlerini Karsilayıc1 Yonde Modern Stadyum Yapılarının Temel Planlama Ozellikleri”, Yayinlanmamis Yuksek Lisans Tezi, Edirne: Trakya Universitesi Fen Bilimleri Enstitusu Mimarlık Anabilim Dali. 2007

[4] Gurel E., Akkoç U.; Stadyum: Benzerlikler, Kosutluklar ve Izdusumler, Uluslararası Sosyal Arastırmalar Dergisi, Cilt:4, sayi: 19, 3, 46-370, 2011

[5] Basgelen, N.; Antik cag kent yasaminda kamusal spor alanlari ve Anadolu gymnasionları. Istanbul: Arkeoloji ve Sanat Yayinlari, 2009

[6] Saltuk, S.; Antik Stadyumlar. Istanbul: Inkilâp Kitabevi, 48-77, 1995

[7] Cutuk, S. ve Zengin, E.; Pergamon (Bergama) medeniyetinde beden egitimi ve spor kulturu ve yonetim stratejilerinin incelenmesi. Spor Yonetimi ve Bilgi Teknolojileri Dergisi, 1(1), 2006

[8] Swaddling, J.; Antik Olimpiyat oyunlari. Istanbul: Homer Kitabevi, 2000

[9] Tekin, A. ve Ekici, S.; Antique sports places in Anatolia. Journal of Sport Tourism, 10(3), 175-186, 2005

[10] K. F. Johansen; Clazomenian Sarcophagus Studies, Acta Arch 13, 1-64,1942

[11] Antik kentler; http://www.kultur.gov.tr/arkeloji, 2000

[12] R. M. Cook; Old Smyrna: The Clazomenian Sarcophagi, BSA $69,55-60,1974$

[13] Durkheim Emile; Sosyolojik Metodun kurallari, çev. Enver Aytekin 15.cilt, 2. baski, Sosyal Yayinlar, Istanbul, 1994

[14] M. J. Mellink; Archaeology in Asia Minor, AJA 88, $441-459,1984$

[15] Izmir, http://www.izmir turizm.gov.tr, 2000

[16] Ramsay WM; Antiquities of southern Phrygia and the border lands. The American Journal of Archaeology and of the History of the Fine Arts. Vol. 3, no. 3/4, 344-368, 1887
[17] Atlas Travellers Journal; Hurriyet Ofset Matbacilik ve Gazetecilik A.S., Istanbul, Nisan, 51-84,1996

[18] Ilhan N, Stadia of Anatolia, Journal of the German National Committee, Bd, 38, 15-20, 2002

[19] Dogan, Cem; "Turkiye Stadyumlari Oturma Elemani Tasariminda Sorunlar ve Bir Cozum Onerisi”, Yayinlanmamis Sanatta Yeterlik Tezi, Istanbul: Mimar Sinan Guzel Sanatlar Universitesi Fen Bilimleri Enstitusu Ic Mimarlik Anabilim Dali, 2007

[20] Yalouris, N.; "The Sanctuary of Olympia", The Olympic Games in Ancient Greece, Editor: Iris Douskou. Athens: Ekdotike Athenan, 88-104, 1982

[21] Alpman C.; Egitim Butunlugu Icinde Beden Egitimi ve Caglar Boyunca Gelisimi, GSB Yayinlari, Istanbul, 59, 1972

[22] İzmir; http://www.izmir-bld.gov.tr, 2000 